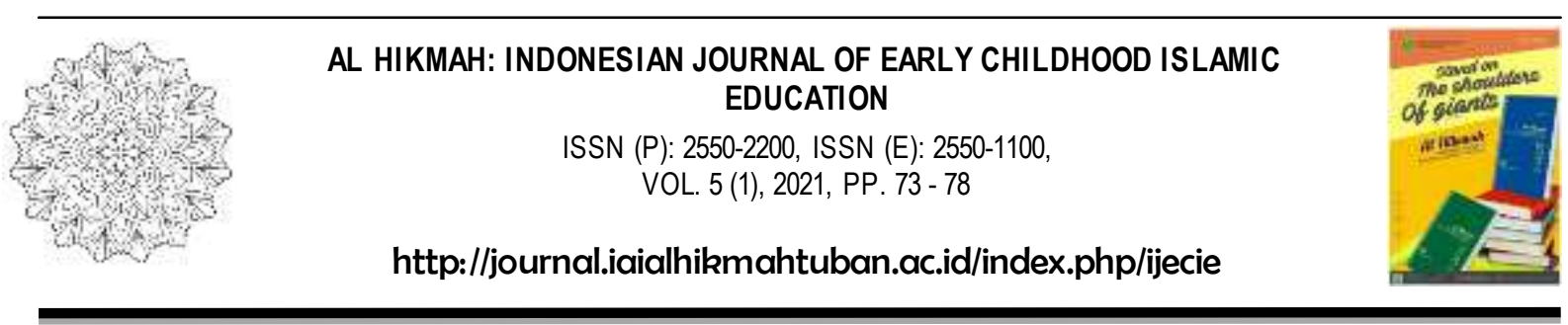

\title{
PERAN GURU DALAM MENGENALKAN SAINS PADA ANAK USIA DINI
}

\author{
Wilma Rahmah Hidayati ${ }^{1}$, Dadan Suryana ${ }^{2}$ \\ ${ }^{1}$ Mahasiswa Magister PAUD FIP UNP \\ ${ }^{2}$ Dosen Magister PAUD FIP UNP \\ wilmarahmahhidayati@g mail.co ${ }^{1}$
}

\begin{abstract}
Abstrak
Penelitian ini bertujuan untuk mengetahui peran pendidik dalam mengenalkan sains pada anak usia dini. Pendidik merupakan aspek terpenting dalam pendidikan disekolah. Namun kenyataan dilapangan masih banyak guru yang belum siap dalam merancang suatu kegiatan yang kreatif. Guru masih memiliki kesulitan dalam mengajarkan pembelajaran sains kepada anak. dan mencari kegiatan-kegiatan sains untuk anak. Penelitian ini menggunakan metode studi literatur yang datanya berasal dari jurnal, artikel, buku-buku dari hasil membaca, mencatat dan menganalisa sesuai dengan permasalahan yang ada. Hasil dan pembahasan pada penelitian ini yaitu untuk melaksanakan proses pembelajaran maka dibutuhkan rancangan pembelajaran (RPPH) sesuai dengan perkembangan kognitif anak mengenai perkembangan sains, menentukan alat dan bahan yang akan digunakan. Pelaksanaannya juga disesauikan dengan perencanaan tersebut dan dilakukan sambil bermain dan belajar, serta melakukan penilaian dengan mengacu kepada STPPA. Kesimpulannya ialah Upaya guru dalam mengenalkan sains yaitu dapat dimulai dari rancangan pembelajaran, pelaksanaan, dan penilaian serta kegiatan yang dilakukan merupakan kegiatan yang menyenangkan dan dilakuakan sambil bermain.
\end{abstract}

Kata kunci: peran guru, sains, anak usia dini

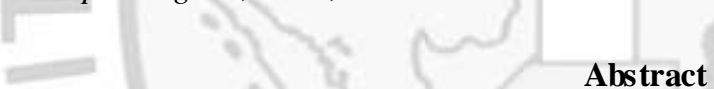

This study aims to find out the role of educators in introducing science to early childhood.Educators are the most important aspect of education in school. But the reality in the field there are still many teachers who are not ready in designing a creative activity.Teachers still have difficulty in teaching children science learning.and looking for science activities for children. This research uses literature study method whose data comes from journals, articles, booksfrom the results of reading, recording and analyzing in accordance with existing problems. The results and discussion in this research is to carry out the learning process, it is necessary to design learning (RPPH) in accordance with children's cognitive development regarding the development of science, determining the tools and materials to be used.The implementation is also regrettable with the planning and carried out while playing and learning, as well as conducting assessments with reference to STPPA.The conclusion is that the teacher's efforts in introducing science can be started from the design of learning, implementation, and assessment and activities carried out is a fun activity and carried out while playing.

Keywords: the role of teachers, science, early childhood 


\section{PENDAHULUAN}

Anak yang berada pada tahap pertumbuhan serta perkembangan fisik maupun mental yang sangat pesat disebut dengan Anak usia Dini. NAEYC (National Association for The Education) menyebutkan anak usia dini yaitu anak yang berusia dari 0 sampai 8 tahun serta berada dalam program pembelajaran di TPA (taman penitipan anak, pendidikan pra-sekolah, TK, dan SD. Undang-Undang RI No 20 Tahun 2003 terkait Sistem Pendidikan Nasional pada Pasal 28 ayat 1 menyebutkan bahwa dilndonesia tentang usia dini ialah 0 hingga 6 tahun sesuai dengan yang terdapat dalam (Wiyani, 2016:98).

Beberapa jalur pendidikan anak usia dini sebelum memasuki tingkat sekolah dasar yaitu jalur pendidikan formal, nonformaal, dan/atau informal. PAUD pada jalur formal antara lain: Taman Kanak-Kanak (TK), Raudatu Athfal (RA), atau bentuk lain yang sederajat. Pada jalur nonformal antara lain: berbentuk Kelompok Bermain (KB), Taman Penitipan Anak (TPA), atau bentuk lainnya yang sederajat. Pada jalur pendidikan informal antara lain: berbentuk pendidikan keluarga atau pendidikan yang diselenggarakan oleh lingkungan sekitar (Saepudin, 2011).

Aspek-aspek perkembangan yang harus dikembangkan sejak dini ialah aspek perkembangan kognitif, fisik-motorik, sosial-emosional, moral dan agama, bahasa dan seni. Salah satu pembelajaran yang dapat mengembangkan keenam aspek tersebut yaitu melalui pembelajaran sains. Pembelajaran sains dapat diterapkan sejak dini karena sejak lahir anak sudah dapat beradaptasi dengan alam dan lingkungan sekitarnya melalui caranya sendiri, dan dengan anak ikut serta dalam proses ilmiah, maka anak bisa mendapatkan keterampilan yang bermanfaat selama hidup mereka.

Menurut Azhari, dkk (2018) anak akan belajar dan menemukan sesutau yang baru sejak berusia dini. Anak memiliki rasa ingin tahu yang tinggi, sehingga anak belajar mengamati atau memperhatikan, menyelidiki dan mencoba hal-hal baru serta sebagainya. Kepandaian ini merupakan kemampuan awal bagi anak memulai belajar dengan sebuah konsep yang dapat memperkaya ilmu pengetahuannya kelak dan berguna bagi kehidupan. Untuk mengembangkan dan menstimulasi kemampuan tersebut disekolah maka di butuhkan peran pendidik yang kreatif.

Guru atau pendidik merupakan aspek terpenting dalam pendidikan disekolah. Terdapat dalam Peraturan Menteri Nomor 137 Tahun 2014 diketahui bahwa pendidik anak usia dini ialah tenaga profesional yang bertugas merancang pembelajaran, melaksanakan pembelajaran, dan menilai hasil pembelajaran, serta melakukan arahan atau bimbingan, 
pelatihan, pengasuhan dan perlindungan. Namun pada kenyataan dilapangan yang kita temui masih bnyak para pendidik yang belum siap dalam merancang suatu kegiatan yang kreatif.

Rahmah (2018) mengatakan bahwa guru masih memiliki persepsi yang berbeda dan sebagian besar guru memahami pembelajaran sains hanya sebatas pemahaman konsep seperti pembelajaran ilmu pengetahuan alam (IPA) saja, sedangkan penerapan untuk anak usia dini (PAUD) khususnya TK masih kurang. Hal ini dikarenakan kemampuan yang guru miliki dalam menyediakan sarana pendukung masih kurang.

Menurut Azhari,dkk (2018) pada observasi awalnya diketahui bahwa 3 sekolah yang ada di kota bandung, sebanyak 20 dari 15 guru masih belum melaksanakan aktivitas pengenalan mengenai pembelajaran sains kepada anak usia dini. Permasalahan yang dihadapi oleh guru diantaranya yaitu guru memiliki sedikit pemahaman mengenai materi pengenalan sains yang akan diberikan kepada anak, guru kesulitan dalam mencari kegiatan-kegiatan sains untuk anak, dan guru masih beum paham dan bingung terhadap pembelajaran apa saja yang bisa dikuasi oleh anak.Menurut Winarni (2017) beberapa guru kurang memahami bagaimana cara membelajarkan sains kepada anak usia dini sehingga guru masih belum membelajarkan sains secara optimal kepada peserta didik. Berdasarkan permasalahan-permasalahana tersebut maka peneliti ingin meneliti terkait upaya guru dalam pengenalan sains pada anak usia dini yang akan mengacu kepada hasil-hasil penelitian sebelumnya.

Pendidikan Anak Usia Dini (AUD) merupakan pembelajaran atau bimbingan yang diberikan kepada anak mulai dari usia 0-6 tahun (di Indonesia) sebagai bentuk fasilitas anak dalam meningkatkan pertumbuhan serta perkembangannya anak secara maksimal. Kemampuan yang diperoleh oleh anak pada seluruh aspek perkembangan dan pertumbuhan mencakup aspek nilai agama dan moral, fisik-motorik, kognitif, bahasa, sosial-emosional, serta seni (Peraturan Menteri No.137 Tahun 2014).

Menurut Nugraha, (2005) ada sebelas tugas guru dalam mengenalkan sains bagi anak usia dini di antaranya: 1) Guru sebagai perencana, 2) Guru sebagai inisiator; 3) Guru sebagai sasilitator, 4) Guru sebagai observer, 5) Guru sebagai elaborator, 6) Guru sebagai antisivator, 7) Guru sebagai antisivator, 8) Guru sebagai model, 9) Guru sebagai evaluator, 10) Guru sebagai teman eksplorasi bagi anak, 11) Guru sebagai promotor agar anak menjadi pembelajar sejati.

Sebaiknya pembelajarann sains sudah diberikan sejak anak berusia dini. Pembelajaran sains yang diberikan kepada anak mencakupproses pengenalan dan penguasaan pada taraf yang sederhana dan sesuai dengan usia anak. Menurut Azhari (2018) prinsip-prinsip 
pendekatan pembelajaran sains pada anak usia dini berorientasi pada kebutuhan dan perkembangan anak, bermain sambil belajar, selektif, kreatif dan inovatif.melalui pengalaman kongkrit, keterampilan-keterampilan yang paling tepat untuk dikembangkan untuk anak usia dini adalah keterampialan dasar mengamati (observing), membandingkan (comparing), mengukur (measuring), mengklasifikasikan (classifying), dan mengkomunikasikan (communicating).

\section{METODE}

Studi Literatur merupakan metode penelitian yang dipakai pada penelitian ini. Sistem pengambilan datanya berdasarkan dari buku-buku atau jurnal-jurnal yang dianalisis sesuai dengan permasalahan yang ada. Menurut Zed (2014:3) studi pustaka atau studi literatur merupakan pengolahan bahan penelitian yang diambil dari hasil membaca dan mencatat sumber-sumber yang ada. Sumber data diambil dari beberapa dokumen-dokumen berupa buku-buku serta jurnal-jurnal hasil penelitian sebelumnya yang relevan dengan penelitian ini. Penelitian ini menganalisa referensi yang bersumber dari jurnal dan buku lalu menghubungkan dengan fenomena yang ada.

Menurut Nazir (2014:27) studi literatur merupakan teknik pengumpulan data dengan mengadakan studi penelaahan terhadap buku-buku, literatur-literatur, catatan-catatan dan laporan-laporan yang ada hubungannya dengan masalah yang dipecahkan. Sebelum menelaah bahan pustaka, peneliti harus mengetahui terlebih dahulu secara pasti tentang dari sumber informasi ilmiah yang mana itu akan diperoleh. Adapun dalam studi kali ini pengumpulakan beberapa buku, jurnal ilmiah serta sumber-sumber lainnya yang relevan dengan kesulitan yang dihadapi oleh guru dalam mengajarkan sains pada anak usia dini. Salah satu sebab mengapa memilih penelitian pustaka ini yaitu karena terhambatnya akses untuk melakukan penelitian ke lapangan karena pandemi COVID'19.

\section{HASIL DAN PEMBAHASAN}

Pendidik mempunyai andil yang sangat besar dalam proses belajar mengajar. Guru memiliki peran mendidik, mengajar, membimbing, melatih, hingga mengevuasi pembelajaran. Peran guru dalam pengenalan sains kepada anak dapat diketahui mulai dari perencanaan pembajaran yang dirancang, meliputi program tahunan, program semester, RPPH dan RPPM. Setelah itu strategi pada pelaksanaan pembelajaran sains dikelas beserta materi-materi yang diberikan yang disesuaikan dengan tema pembelajarannya. Upaya 
penilaian yang dilakukan oleh gurupun dibuat berdasarkan standar tingkat pencapaian perkembangan anak (STPPA). Setelah melakukan penilaian maka dapat dilihat ada tindak lanjut dari hasil penilaiannya tersebut dan selalu melaporkan hasil perkembangan anak kepada orang tua (Azhari.,dkk, 2018).

Sebagian besar pendidik sudah melaksanakan kegiatan pengenalan sains dan mengenal jenis-jenis sains. Guru juga sudah menyajikan pembelajaran sains kepada anak, agar anak mampu lebih aktif. Pelaksanaan pengenalan sains dilakukan dengan kegiatan belajar sambil bermain yang disesuaikan dengan perkembangan anak, minat anak, serta memberikan kesempatan kepada anak untuk bereksplorasi dan mengkomunikasikan hal yang terjadi. Sehingga kegiatan pembelajaran anak menjadi bermakna dan guru mengupayakan proses kegiatan pembelajaran sains disesuaikan dengan kurikulum 2013. Guru mengenal langkah-langkah dalam mengenalkan kegiatan pembelajaran sains menggunakan kegiatan $5 \mathrm{M}$ (mengamati, menanya, mengumpulkan informasi, menalar dan mengkomunikasikan).

Menurut hasil penelitian Octaviani, dkk (2018) perencanaan pembelajaran sains dibuat sebelum pembelajaran dilangsungkan dikelas. Guru membuat RPPH sesuai dengan perkembangan kognitif anak yang secara khusus mengenai perkembangan sains. Pengenalan sains dilaksanakan sesuai dengan tema yang sedang dibahas sehingga anak mendapatkan ilmu yang sesuai. Guru juga mempunyai buku pedoman yang digunakan dalam pengenalan sains untuk anak didiknya. Jika pada pelaksanaannya ada kesulitan bagi anak, maka guru akan membimbing dan memberi motivasi kepada anak untuk menyelesaikan kegiatannya. Jika ada anak yang sudah selesai dengan tugasnya, guru memberikan arahan kepada anak untuk kegiatan selanjutnya.

Berdasarkan beberapa penelitian diatas, dapat kia ketahui bahwa peran guru dalam pembelajaran sains sangatlah dibutuhkan, karena guru berperan dalam mendidik, mnegajar, melatih, dan mengevaluasi pembelajaran yang dilaksanakan disekolah. Sebagai tenaga pendidik guru harus memahammi konsep sains pada pembelajaran anak usia dini, agar tujuan dari pengenalan sains dapat terlaksana secara optimal. Upaya guru pada pembelajaran sains dapat kita lihat bahwa guru membuat terkait perencanaan pembelajaran yang akan dilaksanakan mulai dari kegiatan apa yang akan dilakukan, alat dan bahan seperti apa yang akan digunakan dan setting kelas seperti apa yang akan diterapkan pada pembelajaran sains tersebut. Pelaksanaan pembelajaan juga berlangsung sesuai dengan perencanaan pembelajaran. Pada proses pelaksanaan pembelajaran ini guru akan membimbing dan memberi motivasi kepada anak untuk menyelesaikan kegiatannya dan berkeliling disetiap 
kegiatannta. Upaya penilaian juga dilakukan oleh guru dengan mengacu kepada standar tingkat pencapaian perkembangan anak (STPPA) da dilaporkan kepada orang tua. Pengenalaran kegiatan sains dapat dilakukan dengan kegiatan 5M (mengamati, menanya, mengumpulkan informasi, menalar dan mengomunikasikan.

\section{PENUTUP}

\section{Simpulan}

Pendidikan sains pada anak usia dini merupakan salah satu pembelajaran yang penting bagi pertumbuhan dan perkembangan anak karena melalui pembelajaran sains anak akan mengamati, menanya, mengumpulkna informasi, menalar, serta berkomuniakasi untuk menemukan sesuatu hal yang baru. Upaya guru dalam pengenalan pembelajaran sains ini sangatlah dibutuhkan, karena guru memiliki peran penting dalam pembelajaran disekolah yaitu sebagai motivator dan fasilitator. Pada pembelajaran pengenalan sains, guru membuat perencanaan pembelajaran terlebih dahulu, setelah itu dilaksanakan sesuai dengan yang direncanakan, dan terkahir diniai serta dilaporkan kepada orang tua. Penilaian tersebut mengacu kepada STPPA (Standar Tingkat Pencapaian Perkembangan Anak).

\section{DAFTAR PUSTAKA}

Azhari, dkk. (2018). Upaya Guru dalam Mengenalkan Sains pada Pembelajaran Anak Usia Dini di PAUD Gugus 1 dan 2 Bandung Kulon.

Nazir. (2014). Metode Penelitian. Bogor: Ghalia Indonesia.

Nugraha, Ali.(2008). Pengembangan Pembelajaran Sains pada Anak Usia Dini. Jakarta: Departemen Pendidikan Nasional.

Octaviani, dkk. (2018). Peran Guru dalam Pengenalan Sains pada Anak Kelompok B2 di TK Bina Sari. Jurnal Pendidikan dan Pembelajaran Khatulistiwa, $1-9$.

Peraturan Menteri Nomor 137 Tahun 2014

Saepudin, Asep. (2011). Pembelajaran Sains Pada Program Pendidikan Anak Usia Dini. Jurnal Teknodik, 213-226.

Wiyani, N. A., \& Barnawi. (2016). Format PAUD. Jogjakarta: Ar-Ruzz Media.

Zed, Mestika. (2014). Metode Penelitian Kepustakaan. Jakarta: Yayasan Pustaka Obor Indonesia 